\title{
Framing the fight: Food, history, and meaning in the mess
}

\author{
Review by Jess Gerrior, University of Southern Maine \\ and Antioch University New England*
}

Review of Food Fights: How History Matters to Contemporary Food Debates, edited by Charles C. Ludington \& Matthew Morse Booker. (2019). The University of North Carolina Press. Available as paperback, hardcover, and eBook; 304 pages. Publisher's book page: https://uncpress.org/book/9781469652894/food-fights/

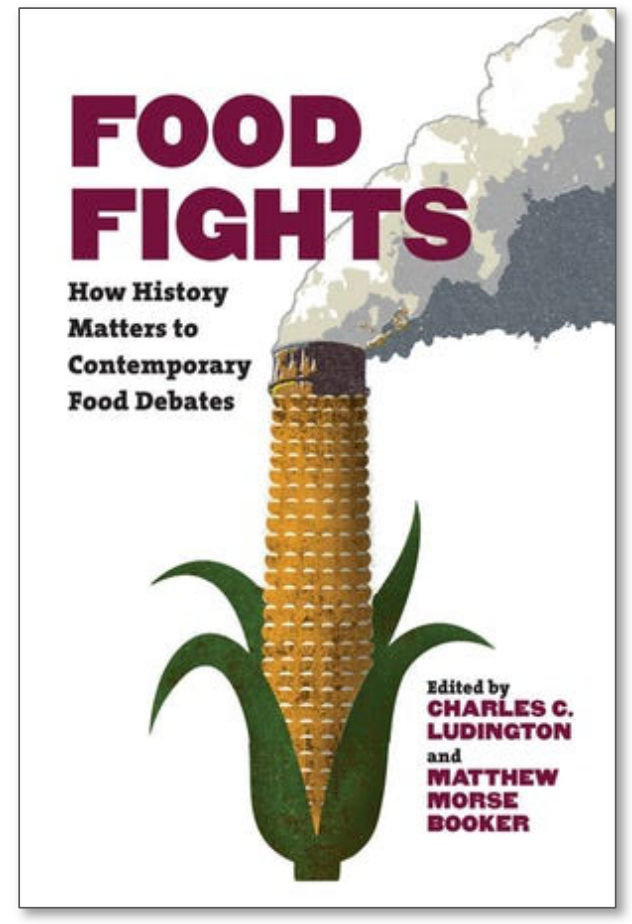

Submitted September 16, 2020 / Published online November 13, 2020

Citation: Gerrior, J. (2020). Framing the fight: Food, history, and meaning in the mess [Book review]. Journal of Agriculture, Food Systems, and Community Development, 10(1), 281-283. https://doi.org/10.5304/jafscd.2020.101.022

Copyright (C) 2020 by the Author. Published by the Lyson Center for Civic Agriculture and Food Systems. Open access under CC-BY license.

Tsues of food systems can be cast in a glaring

light that obscures nuance and polarizes dialogue. We get closer to the truth when we pull back from our present constructions of the issues and

* Jess Gerrior is an adjunct lecturer in food studies at the University of Southern Maine and a doctoral candidate in Environmental Studies at Antioch University New England. Her dissertation uses critical autoethnography to connect social identity and gardening in the context of community food system efforts involving higher education institutions. Her doctoral service project, "Cultivating Community," is a photographic and narrative portrayal of how people in the Monadnock Region experience their work in local food systems. She currently serves as a network leader with the New Hampshire Food Alliance, a garden educator with The Cornucopia Project, and a gardener building community food resilience. She can be contacted at jess.gerrior@maine.edu allow ourselves to experience the dynamic, marvelously complicated stories of how they have formed, what forces drove them, and how those forces affect us still. Such histories entail tension and convergence, missed opportunities, best-laid plans, and unintended consequences. The understandable impulse may be to avoid difficult and even painful realizations of how entangled food has become with larger issues of class, identity, and political economy. The authors of Food Fights do not let us off the hook. They invite us instead to walk back through these issues more deeply, more critically, using a historical frame that allows us to see the issues, if not more clearly, at least more honestly.

The book's attempt to "bring a critical histori- 
cal eye to food studies" (p. 3) matters because it recognizes the limitations as well as the contributions that the natural sciences, social sciences, and humanities have brought to the table thus far. In many respects, the book achieves that aim. Its section on "Choosing Food" does an excellent job of helping the reader see how issues of class play in who eats what foods and why, and the implications of food choice for socially constructed measures of health. Here, too, is where the book could have looked more closely at certain historical moves that have shaped food insecurity today, specifically why programs like the Supplemental Nutrition Assistance Program (SNAP) and Women, Infants, and Children (WIC) may not deliver the benefits they intended. This gap is addressed in Andrew Fisher's discussion of the "hunger-industrial complex" in Big Hunger: The Unboly Alliance Between Corporate America and Anti-Hunger Groups (2017). Additionally, some chapters characterize farming as a singular entity and farmers as a homogenous group, seeming not to recognize the vast differences in the impacts of food policy on large, industrial, and conventional farms and small, independent, and organic farms, as well as which farmers' voices (mainly the former) are heard at the policy table.

Food Fights does a good job of portraying the various forms of food activism and explaining the motivations and limitations of "alternative" food movements in the context of American, capitalist food systems. However, while it offers valuable perspectives on class and gender as they relate to food, the book glosses over the issue of race. For example, Chapter 3, where Steve Striffler rightly describes American agriculture as a "profoundly unequal system defined by powerful companies and an exploited labor force" (p. 66), would have been the place to name structural racism. Whether our nation's legal enslavement of African people and subsequent discrimination against Black Americans, the cultural assimilation of Native Americans, reliance on the cheap labor of Latin and Asian immigrants, or disproportionate exposure of migrant workers to toxic agricultural chemicals, the book missed opportunities to confront structural racism by naming its role in our modern food system.

The book would pair well with Timothy Wise's
Eating Tomorrow: Agribusiness, Family Farmers, and the Battle for the Future of Food, which dedicates a section to "The Roots of Our Problems." Both books offer lessons about food actors landing on the wrong side of history. Both books' conclusions propose the importance of balance. In Eating Tomorrow, it is about restoring balance in our agricultural ecosystems by achieving "a reasonable balance between family farmers and agribusiness" (p. 276), a statement that shows care for the distinction between these very different operations of food production. In Food Fights, it is about a "twin program" of continuing to use what is working and daring to name what has since become maladaptive, so that that food can become more equitable, enjoyable, and environmentally sound.

As they trace the multiple threads in America's history, the authors of each chapter "enter the fray" by problematizing assumptions of both "those would romanticize the past" (p. 7) and those who find no problems with the current food system. As they articulate their positions, the authors show how people can look at the same set of facts and come to different conclusions based on their frameworks. This makes the text wellsuited to critical food studies. The book does a particularly impressive job of letting the reader experience the chapters "speaking" to one another. It reads cohesively, like being in a conference with colleagues who may fundamentally disagree, but lend one another an attuned and respectful ear and welcome the reader into the conversation.

Academics should consider Food Fights for an intermediate seminar in food studies or any course dealing with social problems where food might present a case study for larger sociopolitical issues to support critical discourse and develop critical research questions. Chapters could be integrated into an introductory food studies course, so long as students are familiar with (or the instructor provides background on) topics like the farm bill, nutrition policy, and economics. Readers may benefit by first reading Dan Barber's The Third Plate: Field Notes on the Future of Food (2014) for a sense of the landscape of issues that Food Fights seeks to illuminate.

By partaking in more nuanced debate framed and informed by history, readers may find them- 
selves less inclined to accept an oversimplified version of our current food reality and instead embrace a more meaningful, messy one. The authors' appreciation for social context imparts a respect for food studies as a history in progress. It highlights the importance of understanding the impact of precedent on contemporary food problems because overlooking the past narrows our scope of future solutions. Revealing historical underpinnings in food studies also offers hope that more food scholars, activists, and other change agents may find history alive and even alluring.

\section{References}

Barber, D. (2014). The third plate: Field notes on the future of food. New York: Penguin Books.

Fisher, A. (2017). Big bunger: The unholy alliance between corporate America and anti-bunger groups. Cambridge, MA: MIT Press. https://doi.org/10.7551/mitpress/10987.001.0001

Wise, T. A. (2019). Eating tomorrow: Agribusiness, family farmers, and the battle for the future of food. New York: The New Press. 